\title{
Nimiä Karjalasta kokemuksella
}

Saulo Kepsu: Kannaksen kylät. Kotimaisten kielten keskuksen verkkojulkaisuja 54. Helsinki: Kotimaisten kielten keskus 2018. 542 s. ISBN 978-952-5446-92-0. Luettavissa osoitteessa http://scripta.kotus.fi/www/ verkkojulkaisut/julk54/Kannaksen_kylat. pdf

Laila Lehikoinen: Antreasta Äyräpäähän. Luovutetun Karjalan pitäjien nimet. Kotimaisten kielten keskuksen verkkojulkaisuja 55. Helsinki: Kotimaisten kielten keskus 2018. 52 s. ISBN 978-952-5446-93-7. Luettavissa osoitteessa http://scripta. kotus.fi/www/verkkojulkaisut/julk55/ Antreasta_Ayrapaahan.pdf

Nimet ja historia kiinnostavat ihmisiä. Luovutettu Karjala on aihe, josta on laadittu erilaisia historiikki- ja muistelmateoksia ehkä enemmän kuin mistään muusta Suomeen kuuluvasta tai kuuluneesta alueesta. Karjalan paikannimistä ei kuitenkaan ole paljoa kirjoitettu sitten 1970-luvun, jolloin Viljo Nissilä (1975) julkaisi teoksensa Suomen Karjalan nimistö. Kotimaisten kielten keskuksen vastikään julkaisemat kaksi teosta, Saulo Kepsun Kannaksen kylät ja Laila Lehikoisen Antreasta Äyräpäähän: Luovutetun Karjalan pitäjien nimet, vievät nimistöntutkimuksen takaisin luovutettuun Karjalaan. Näistä ensimmäinen on laaja ja perusteellinen selvitys Karjalan Kannaksen asutusnimistä, jälkimmäinen vuorostaan tiivis katsaus luovutetun Karjalan pitäjien nimiin.

Molemmat kirjoittajista ovat filosofian tohtoreita ja jo pitkään vaikuttaneet nimistöntutkimuksen parissa. Kepsu on 1950-luvulta lähtien harrastanut erityisesti asutusnimiin keskittynyttä tutkimusta, ja hänen työnsä ovat tuoneet lisätietoa esimerkiksi Pohjois-Kymenlaakson (1981) ja pääkaupunkiseudun (2005) asutushistoriasta. Lehikoinenkin on jo pitkään toiminut paikannimien parissa, ja erityisesti hänen väitöskirjansa Kirvun talonnimet: Karjalaisen talonnimisysteemin kuvaus (1988) on edelleenkin teos, johon useasti viitataan nimistöntutkimuksessa.

\section{Perusteellisesti Kannaksen asutusnimistä ja -historiasta}

Kepsun Kannaksen kylät on perusteellinen katsaus Karjalan kannaksen Suomeen kuuluneen osan monikieliseen asutusnimistöön. Teoksen taustalla on vuosikymmenien tutkijanura sekä tuhansien tuntien työ. Kirjoittajan tavoitteena on ollut selvittää nimien taustoja ja antaa uutta tietoa Kannaksen sekä lähialueiden asutushistoriasta. Tutkimusaineisto on koottu pääosin vanhoissa asiakirjalähteissä esiintyvistä asutusnimistä. Näistä suurin osa on kylännimiä, jotka on mainittu 1500- ja 1600-luvuilla joko ruotsalaiseen tai venäläiseen verotukseen liittyvissä asiakirjoissa.

Teoksen alun johdannossa Kepsu käy läpi tutkimuksen taustaa ja käytettyjä tutkimusaineistoja. Tämän jälkeen esitellään nimistöntutkimuksen ja erityisesti asutushistoriallisen nimistöntutkimuksen perusteita. Näin lukijalle muodostuu selkeä kuva siitä, minkälaisten olettamusten varaan tavoite Kannaksen asutushistorian selvittämisestä rakentuu. Kepsu käy myös perusteellisesti läpi erilaiset nimityypit, joihin hänen tutkimansa kylännimet voidaan jakaa. Näistä ensimmäisenä esitellään oletettavasti vanhimpaan kerrostumaan kuuluvat luonto- ja viljelysnimipohjaiset asutusnimet, kuten Petäjärvi, Haapaniemi, Perojoki, Maamäki ja Saviselkä. Henkilönnimikantaiset asutusnimet on yläkäsite, jonka alle Kepsu on 
sijoittanut aikajärjestyksessä omiksi luokikseen esikristillisiin (esim. Himottula ja Kaukolempiälä), ortodoksisiin eli venäläisiin (Junttola, Mälkiä, Baklanovo ja Dudina) sekä läntisiin henkilönnimiin (Hannukkala ja Sunikkala) perustuvat asutusnimet.

Kirjoittaja selvittelee myös Vatjan viidenneksen verokirjoissa esiintyvää ItäKannaksen runsasta venäjänkielistä ja venäläisasuista paikannimistöä (esim. Berezov navolok, Bojarskoje, Hmelevaja, Košurkino, Sotkujevo) ja tulkitsee sen enimmiltä osin kirjurinkäännöksiksi ja joskus venäläisten maanomistajien nimiksi. Toisinaan tekijä toteaa venäjänkielisen paikannimen vakiintuneen paikallisten karjalaisten käyttöön (esim. Konnitsa, Kontsa, Porkku, Putoria, Saapru), ja toki löytyy myös osittaisia käännöksiä (Suurporkku). Lisäksi Kepsu käsittelee edellä mainittujen luokkien ulkopuolelle jääviä tapauksia, kuten etnonyymin sisältäviä Lapin-, Venäjä-, Häme-, Vepsätai Suome-alkuisia asutusnimiä.

Nimiluokkien esittelyn jälkeen vuorossa on ehkä teoksen tärkein osio eli katsaus Karjalan kannaksen asutushistoriaan. Kepsun päätelmät perustuvat pääosin hänen tutkimiinsa asutusnimiin, mutta myös arkeologian tutkimustuloksilla ja vanhoilla verotustiedoilla on suuri merkitys. Katsaus on jaettu osiin 1500-luvun pogostojen ja pitäjien mukaisesti, jotka käydään läpi seuraavanlaisesti: Ensiksi käsitellään Novgorodin verotusvaltaan kuuluneet Rautu, Sakkola ja niin sanottu Kaupungin pogosta (pogost Gorodenskoi). Näitä seuraavat Ruotsiin kuuluneet pitäjät Äyräpää ja Jääski. Jokaisen kohdalla Kepsu esittelee tiedot alueen maantieteestä, viljelysoloista, arkeologisista löydöistä sekä verotiedoista ja yhdistää nämä tiedot asutusnimien antamaan informaatioon. Tämän pohjalta Kepsu piirtää kuvan pogostojen ja pitäjien asutuskehityksestä: mitkä asutuskeskittymät ovat vanhimpia, mitkä nuorempia, mistä alueelle on tullut asukkaita tai mihin suuntiin alueelta on muutettu. Kannaksen osalta hän esittelee laajimmin Suomenlahden pohjoispuolisia asutusvirtoja. Hän löytää Kannakselta seitsemän vanhaa asutuspesäkettä, joista asutus on myöhemmin alkanut levitä muualle. Näistä alueista vanhimmaksi hän päättelee jo arkeologisiltakin löydöiltään runsaan Räisälän-Käkisalmen-Kaukolan seudun. Lopuksi kirjoittaja vielä kokoaa yhteen päätelmänsä ja esittää tiivistetyn katsauksen Kannaksen asutushistoriasta.

Asutushistorian tarkastelua seuraa yhtä lailla perusteellinen Kannaksen asutusnimien analyysi. Kaikkiaan noin 2000 nimeä sisältävä aineisto käsitellään aakkosjärjestyksessä. Jokaisesta käsiteltävästä nimestä esitetään oleelliset taustatiedot, joita ovat nimen murteellinen kirjoitusasu, useimmat vanhat asiakirjamuodot ja kylän sijainti 1900-luvun alun pitäjäjaossa. Lisäksi tarjotaan mahdollinen linkki kylän sijaintiin www.karjalankartat.fi-sivuston kartalla. Novgorodin verokirjojen nimiasut on esitetty pelkästään latinalaisin kirjaimin, mistä harvakseltaan aiheutuu pientä epäselvyyttä. Kepsu on myös laatinut jokaiselle nimelle hypoteesin sen alkuperästä eli etymologiasta. Lisäksi hän on mahdollisuuksien mukaan vertaillut nimeä muihin samankaltaisiin nimiin sekä laatinut arvionsa nimeen liittyvistä asutushistoriallisista päätelmistä. Aineiston valtavasta määrästä johtuen etymologioihin on toisinaan jäänyt pohtimisen aihetta niin monikielisyyden kuin merkityksienkin osalta.

\section{Luovutetun Karjalan pitäjistä ja niiden nimistä}

Lehikoisen teos Antreasta Äypäpäähän: Luovutetun Karjalan pitäjien nimet on ytimekäs katsaus luovutetun Karjalan pitäjien nimiin. Kuten nimestäkin voi päätellä, Lehikoisen tutkimusalue on maantieteellisesti laajempi kuin Karjalan kannaksen asutusnimiin keskittyvässä Kepsun 
teoksessa. Lehikoisen teos on jaettu nimiartikkeleihin siten, että jokaisesta luovutetun kunnan nimestä on oma lyhyt artikkelinsa. Mukana on myös epävirallisia sekä ennen toista maailmansotaa käytöstä poistuneita pitäjännimiä.

Yhteensä nimiartikkeleita on 56 kappaletta. Jokaisessa on samanlainen rakenne. Aluksi kuvataan pitäjän sijainti, minkä jälkeen luetellaan lähialueen paikat, joiden nimistä löytyy tutkitun pitäjän nimi (esimerkiksi Heinjoelta löytyy Heinjoki-niminen oja). Luonnollisesti myös pitäjännimen vanhoja asiakirjamuotoja esitellään. Vanhoissa venäläisissä asiakirjoissa mainitut nimet on tosin esitetty vain translitteroituina eikä kyrillisin kirjaimin, joilla ne on alun perin kirjattu. Lisäksi esitetään jokaisen pitäjän historiasta lyhyt kuvaus. Nimien alkuperän selvittämisessä mielenkiintoista antia artikkeleissa ovat niin sanotut kansanetymologiat, joissa kuvataan sitä, minkälaisia selityksiä tavalliset ihmiset ovat antaneet tutkittavan nimen alkuperästä. Tämän jälkeen käydään läpi tieteelliset teoriat nimen etymologiasta. Suurimmassa osassa artikkeleita on Kepsun teoksen tapaan linkki, josta on mahdollista nähdä pitäjän keskus www.karjalankartat. fi-sivuston kartalla. Jokaisen nimiartikkelin lopuksi on esitetty yhtenä listana lähteet, joihin artikkelin tiedot perustuvat. Mielenkiintoinen yksityiskohta on se, että miltei jokaisen nimiartikkelin kohdalla on viitattu Kepsun yllä käsiteltyyn teokseen. Tämä on tietysti luontevaa, koska Kepsulta löytyvät analyysit samoista nimistä, joita Lehikoinen käsittelee.

\section{Yhteenveto}

Kepsun ja Lehikoisen teokset ovat molemmat sellaisia, että ne varmasti herättävät mielenkiintoa Karjalan menneisyydestä kiinnostuneiden parissa. Näistä Kepsun Kannaksen kylät lienee hyödyllisempi tutkijoille, kun taas Lehikoisen opus on sopivampi luovutetun Karjalan pitäjien historiasta kiinnostuneille harrastajille. Molemmissa teoksissa lukijaystävällisyyttä olisi voinut parantaa täydentämällä leipätekstiä karttojen ja kuvien avulla. Kepsulla on useita mainintoja erilaisista levikkikartoista, joita hän on tehnyt tutkimustaan varten tai käyttänyt aiemmissa teoksissaan. Niistä olisi ollut hyötyä myös käsillä olevassa julkaisussa, sillä ne olisivat auttaneet lukijaa ymmärtämään esimerkiksi sitä, mistä kaikkialta Itämeren piiristä löytyy esikristillistä henkilönnimiainesta. Yhtä lailla Lehikoisen teokseenkin olisi voinut lisätä esimerkiksi jokaisen nimiartikkelin yhteyteen kartan, jossa näkyy pitään sijainti ja rajat ennen toista maailmansotaa. Visuaalisuuden puutetta ei voi ainakaan painokustannuksilla perustella, koska molemmat opukset on julkaistu vain sähköisesti.

Lopuksi vielä sananen Kepsun teoksessa käytetystä nimityksestä Kaupungin pogosta. Kyse on vakiintuneesta mutta hieman harhaanjohtavasta käännöksestä, jonka sijaan toivoisi vastaisuudessa käytettävän joko alkuperäistä asiakirja-asua Gorodenskoi pogost tai vaihtoehtoisesti nimitystä Karjalan tai Korelan jollei peräti Käkisalmen pogosta - Karjalan ydinalueesta ja syntypaikastahan siinä mitä ilmeisimmin on kysymys.

Joka tapauksessa on selvää, että molemmat teokset ovat hyvin ja huolellisesti tehtyjä. Erityisesti Saulo Kepsun rautaisesta asiantuntemuksesta suomalaisen ja myös koko Itämeren piirin nimistön saralla on erittäin paljon hyötyä kaikenlaisille tutkijoille aina sukututkijoista arkeologeihin. Tämän vuoksi on hienoa, että Kotimaisten kielten keskus julkaisee kokeneiden tutkijoiden töitä verkossa avoimesti. Näin varmistetaan, että pitkä ja arvokas työ ei jää vain kirjoittajien omaan tietoon, vaan kaikki kiinnostuneet pääsevät nauttimaan Kepsun ja Lehikoisen tietotaidosta. 


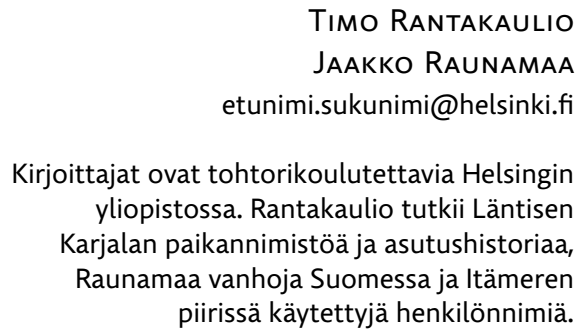

\section{Substantiivien moniulotteisista merkityksistä}

Zhengdao Ye (toim.): The semantics of nouns. Oxford: Oxford University Press 2017. 315 s. ISBN 978-0-19-873672-1.

"En voi istua vieressäsi", sanoi eräs rouva minulle kahvitellessamme Tukholman suomalaisella kirkolla reilu vuosi sitten. "Olin ajatellut jutella jonkun kanssa, mutta sinua en tunne." Sen jälkeen hän vaihtoi paikkaa. - Esimerkiksi tämä tapaus muistui mieleeni lukiessani Zhengdao Yen toimittamaa teosta substantiivien merkityksestä. Siinä kerrotaan muun muassa kiinan kielen sanoista, joita käytetään tutuista ja vieraista ihmisistä. Teoksessa käsitellään substantiivien merkityksiä niin sanotun alkusanakielen (Natural Semantic Metalanguage) avulla, jonka Anna Wierzbicka (1996) ja hänen seuraajansa ovat kehittäneet. Alkusanakielen idea on identifioida rajallinen määrä käsitteitä, joille löytyy sana kaikista maailman kielistä ja joiden avulla kaikki

\section{Lähteet}

KePsu, Saulo 1981: Pohjois-Kymenlaakson Kylännimet. Helsinki: Suomalaisen Kirjallisuuden Seura.

- 2005: Uuteen maahan. Helsingin ja Vantaan vanha asutus ja nimistö.Helsinki: Suomalaisen Kirjallisuuden Seura.

Lehikoinen, LAILA 1988: Kirvun talonnimet. Karjalaisen talonnimisysteemin kuvaus. Helsinki: Suomalaisen Kirjallisuuden Seura.

Nissilä, Viljo 1975: Suomen Karjalan Nimistö. Joensuu: Karjalaisen kulttuurin edistämissäätiö. muut kaikkien kielten käsitteet ja sanat voidaan selittää. Kirja on kiinnostavaa ja hyödyllistä luettavaa myös sellaisille, jotka eivät tutkimuksessaan käytä juuri kyseistä metodia. ${ }^{1}$ Sen toimittaja työskentelee kiinan kielen ja kirjallisuuden lehtorina Australian kansallisyliopistossa (Australian National University) ja on julkaissut monia artikkeleita, joissa hän käyttää metodinaan alkusanakieltä.

Johdantoluvussa Ye asettaa kirjalle kaksi päätavoitetta. Tarkoitus on yhtäältä valaista substantiivien merkityksiä eri kielissä, toisaalta mallintaa eri domeeneihin kuuluvia substantiiveja. Toisin sanoen ajatuksena on, että erityyppisiin asioihin viittaavia substantiiveja

1. Ajantasaista ja kattavaa tietoa alkusanakielestä on tarjolla sivustolla https://intranet. secure.griffith.edu.au/schools-departments/ natural-semantic-metalanguage. Ks. suomenkielinen yleisesittely Vanhatalo \& Tissari 2017. 